\title{
Competencies for educators in delivering digital accessibility in higher education
}

John Gilligan

Technological University Dublin, john.gilligan@tudublin.ie

Follow this and additional works at: https://arrow.tudublin.ie/ittscicon

Part of the Computer Sciences Commons

\section{Recommended Citation}

Gilligan J. (2020) Competencies for Educators in Delivering Digital Accessibility in Higher Education. In: Antona M., Stephanidis C. (eds) Universal Access in Human-Computer Interaction. Applications and Practice. HCII 2020. Lecture Notes in Computer Science, vol 12189. Springer, Cham. https://doi.org/ 10.1007/978-3-030-49108-6_14

This Conference Paper is brought to you for free and open access by the School of Science and Computing at ARROW@TU Dublin. It has been accepted for inclusion in Conference Papers by an authorized administrator of ARROW@TU Dublin. For more information, please contact arrow.admin@tudublin.ie, aisling.coyne@tudublin.ie,gerard.connolly@tudublin.ie.

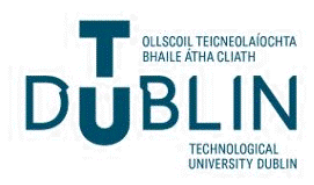




\title{
Competencies for Educators in Delivering Digital Accessibility in Higher Education
}

\author{
John Gilligan ${ }^{(\bowtie)}$ \\ Technological University, Dublin, Ireland \\ john.gilligan@tudublin.ie
}

\begin{abstract}
The aim of this paper is to critically review the capabilities of the European Framework for the Digital Competence of Educators (DigCompEdu) and the UNESCO ICT Competency Framework for in delivering greater accessibility for students with disabilities in a Higher Education landscape undergoing Digital Transformation. These frameworks describe what it means for educators to be digitally competent. However are there other competencies required to deliver Digital Accessibility in education. The particular focus of this paper is the role of the teachers in delivering Digital Accessibility in higher education. What should be expected of them and what are the required competencies to meet these expectations? Is it fair for example to expect teachers to cross boundaries where the effectiveness of general accessibility strategies such as UDL end for particular groups of students for example blind students in STEM subjects and where there is a need for individualised accommodations?
\end{abstract}

Keywords: Digital Accessibility $\cdot$ Competency frameworks $\cdot$ Digital transformation in education

\section{Introduction}

\subsection{Digital technology}

Digital technology, whether in the form of computing, the internet, mobile phones, digital TVs, smart technology and lately the Internet of Things, has emerged as a pervasive ubiquitous feature of modern life. Emerging technologies will necessitate a constant evolution of ways of working, systems and processes across the system, with the aim of adding value to the users, [1]. There are many responses to this challenge. The European Digital Strategy is one for example. [2] There are wide ranging programmes underway, from Building a European Data Economy to investing in Information and Communications Technology (ICT) Research and Development.

Higher education is no different. It must embrace Digital Transformation in a strategic cohesive way. However in the face of the rapidly changing landscape of digital technology in education there is an uneven response to the challenges. The European Higher Education Area in 2018 report provides an overview of the situation regarding national strategies and policies on the use of new technologies in teaching and learning across the European Higher Education Area, [3]. Of fifty countries aligned to the European Higher Education area, three have a strategy on the use of new 
technologies in education. Eighteen have broader national strategies which include technologies in education. Seventeen do not have national strategies but have policy measures to encourage progress and twelve have neither strategy or policy. Of the thirty eight countries that had strategies or policies in place the three main areas identified for allocation of additional funding to support digital transformation in higher education were: digital infrastructure; the development of skills of higher education staff to use digitally-based methods in their teaching; and, improving student's digital skills.

In November 2017, at the Gothenburg Summit, the European Parliament, the Council and the Commission reaffirmed the right to high-quality and inclusive education, training and life-long learning. [4] In response the EU's European Education Area initiative, has in 2018 developed a Digital Education Action Plan, which includes 11 actions to support technology-use and digital competence development from primary to third level education, [5]. Actions are grouped into three main areas, namely: making better use of digital technology for teaching and learning; developing digital competences and skills; and, improving education through better data analysis and foresight. One of the key actions in relation to higher education will be the creation of an EU-wide online platform will be created to support Higher Education institutions (HEIs) in using digital technologies to improve the quality and relevance of learning and teaching, to facilitate internationalization and support greater cooperation between HEIs across Europe.

The focus of this paper is Digital Competencies and accessibility. Digital technology can be an enabler of accessibility. The provision of electronic notes in the form of presentations and PDF can provide ready access to course notes in advance of lectures. Videos and Podcasts can provide interesting alternative ways to present course material and demonstrate skills and techniques. Good websites can be invaluable sources of information. Virtual Learning Environments offer useful learning dissemination and management environments. Indeed the role of the teacher/lecturer has evolved to be a content provider across these multiple technologies.

Rapid advances in ICTs have provided the opportunity to create entirely new learning environments by significantly increasing the range and sophistication of possible instructional activities in both conventional and e-learning settings, [6]. A wide diversity of powerful and readily available technological tools offer myriad opportunities for transforming pedagogy through the adoption of learner-centered instructional approaches. Multimedia tools such as YouTube, blogs, wikis, podcasts, social networks such as Facebook and Twitter, virtual worlds, RSS feeds, social bookmarking, etc. can offer novel and creative ways of teaching that can address a variety of learning styles. They can inspire innovative teaching methods that stimulate collaboration among learners, creation and sharing of information, and development of online learning communities. In order to affect Accessible Digital Transformation in education educators must have the necessary competences.

Digital Competence has been at the centre of European policy for many years. For example, digital competence was identified as one of the eight key competences for lifelong learning for EU citizens in 2006, [7]. More recently in January 2018, a set of recommendations for improving digital competence was published, extending its definition to cover coding and cybersecurity, [8]. 
Since 2014, the European Commission's working group on Digital and Online Learning (DOL, 2014-15) and the subsequent working group on Digital Skills and Competence (DSC, 2016-18) have been responsible for supporting policy actions aimed at the digital innovation of education in the EU, contributing to the development of the following tools:

European reference frameworks and related tools to support the development of DSC for citizens (DigComp 2.1), [9], teachers (DigCompEdu), [10] and educational organisations (DigCompOrg), [11].

The specific focus of this paper is the participation of students with disability in higher education and the need to build competency frameworks around digital accessibility to support this. We will look at how digital competence frameworks for educators such as the DigCompEdu and the UN ICT Competency Framework for Teachers, [12] can be used as the basis for describing a framework of digital accessibility competences for educators.

\subsection{Digital Competency Frameworks for Educators}

The UNESCO ICT Competency Framework of 2018 (ICT CFT Version3) is the third version of the framework building on earlier works in 2008 and 2011. It provides a comprehensive set of competencies necessary for teachers to integrate technology to facilitate students' achievement of curriculum goals, [12].

The ICT CFT Version 3 takes into account the Agenda 2030 for Sustainable Development, [13]. ICTs are critical for progress towards the achievement of all 17 Sustainable Development Goals (SDGs). ICT related targets are addressed specifically in a number of the goals for example in Goal 9, Infrastructure and Goal 10, Reduced inequalities within and across countries. Goal 4 Quality education is of obvious interest here. Technology has the innovative potential to enable learners to access information and knowledge and to more fully participate in education like never before. This in turn enables digital citizenship - the ability and ethical values to participate in society online - which is a central aspect of modern life.

The ICT CFT consists of 18 competencies organized according to the six aspects of teachers' professional practice, over three levels of teachers' pedagogical use of ICT. The six aspects of a teacher's professional practice addressed are:

1. Understanding ICT in Education Policy;

2. Curriculum and Assessment;

3. Pedagogy;

4. Application of Digital Skills;

5. Organization and Administration; and

6. Teacher Professional Learning.

These are considered over three levels, namely Knowledge Acquisition, Knowledge Deepening and Knowledge Creation. Examples of the competences include Policy Understanding at the Knowledge Acquisition level of the Understanding ICT in Education aspect to Knowledge Society skills at the Knowledge Creation level for Curriculum and Assessment, [12]. 
Like the UNESCO ICT CFT Version 3 framework the European Framework for the Digital Competence of Educators (DigCompEdu) was also was published in 2018. The DigCompEdu study is based on the previous work carried out to define the Digital Competence of the citizens, in general and the Digitally Competent Education Organisations (DigCompOrg), [10]. It contributes to the Commission's recently endorsed Skills Agenda for Europe.

DigCompEdu provides a general reference frame to support the development of educator-specific digital competences in Europe It is directed towards educators at all levels of education, from early childhood to higher and adult education. DigCompEdu details 22 competences organised in six competency areas. These are:

1. Professional Engagement

2. Digital Resources

3. Teaching and Learning

4. Assessment

5. Empowering Learners

6. Facilitating Learners' Digital Competence

These are defined over six levels of proficiency from newcomer to pioneer. Examples of the competences outlined Creating and Modifying in the Digital resources competence area to the provision of Feedback and Planning in the Assessment area.

There isn't direct alignment for the most part, between the competency aspects of the UNESCO Framework and the competency areas of the DigCompEdu framework. In some cases there is a strong correlation. For example Aspect II of the UNESCO framework Curriculum and Assessment which explores how ICT might support the specific objectives as identified in the curriculum, and play a role in supporting assessment aligns well with DigCompEdu competency area of Assessment which considers the use of digital technologies and strategies to enhance assessment.

Contrast this with Aspect 1 Understanding ICT in Education Policy which encourages teachers to be aware of how ICT might be aligned to national education priorities or Aspect VI: Teacher Professional Learning which could both be aligned with all of the competency areas of the DigCompEdu because policy and Teacher Education should embrace all aspects of digital technology in education. Other aspects of the UNESCO Framework dovetail to a strong degree with different competence areas of the DigCompEdu. For example Aspect IV Pedagogy links in with at least Area 3 Teaching and Learning and Area 6 Facilitating Learners Digital Competence and the Differentiated Learning Strategies considered in Area 5 Empowering learners However some elements of the DigCompEdu Framework are considered as Cross-cutting principles of the UNESCO framework and are outside the scope of the specified Aspects.

While both frameworks recognize the requirement that all competences need to consider accessibility and provide examples of the necessary skills required but they do not provide the necessary detail to demonstrate how each competency in the framework can be augmented with accessibility. In the following sections the requirements for a digital competence framework which considers digital accessibility will be explored. 


\section{Towards a Digital Accessibility Competency Frameworks for Educators}

The rise of digital technologies in Higher Education leads to the question of how all this transformation impacts students with disabilities. Despite issues with evidence gathering, [14] people with disability are an increasing presence in higher education and this demands an appropriate response to ensure accessibility and inclusion.

From the 1994 UNESCO Salamanca declaration which advocated the mainstream education of people with disabilities, [15] through to the 2006 United Nations Convention on the Rights of People with Disability, [16] and beyond, the issue of the inclusion of people with disability in higher education has been insisted on as a right. The Agenda for Sustainable development of the UN of 2013 embraces inclusive education under Goal 4, [17]: "Ensure inclusive and equitable quality education and promote lifelong learning opportunities for all", which includes "build and upgrade education facilities that are child, disability and gender sensitive and provide safe, nonviolent, inclusive and effective learning environments for all".

In spite of this, the relative numbers and rates of students with disabilities in higher education according to Academic Network of European Disability experts (ANED), [18] is still very low compared to their nondisabled peers. For example, in Ireland between 2000 and 2006, while the rate of participation for disabled students increased by $2.6 \%$, the overall rate of access to tertiary education rose at a much higher rate, namely $8 \%$.

Digital technologies can be critical enablers of education, opening new avenues for learning and transforming the learning experience. Digital technology too can facilitate inclusion. Nevertheless, these rapidly changing scenarios present unique challenges to the participation of people with disabilities in Higher Education. Content must be accessible. It must be usable with the variety of Assistive Technologies such as screen readers that are used. Digital competences now become a vital part of the education of learners with disabilities as more and more technology is used in the classrooms and lecture halls. The diversity of learning requirements insists on flexible and innovative curricula and assessment strategies to meet this variety of needs.

The consequence of not embracing these challenges presents real difficulties for many people. The 2016 European Network for Technology Enhanced Learning in an Inclusive Society (ENTELIS) white paper on Digital Inclusion highlights the potential of a digital divide where certain groups are left behind as technological innovation grows due to unforeseen barriers that arise, [6]. With regard to digital content and technology these barriers may manifest themselves as inaccessible content, poorly designed applications, inflexible curricula, unsuitable learning and teaching strategies and lack of training is. As the number of students with disabilities grows there has been a response.

\subsection{Initiatives at European Level}

There are a number of efforts at a European level which look at the participation of people with disabilities in education. None are focused specifically on the participation of people with disabilities in higher education in this age of Digital Transformation. 
They address elements of this but not in its entirety. They are either focused on levels other than higher education or have some other focus. For example the goal of UDLnet-Universal Design for Learning project is to establish a network for promoting the principles of UDL in the primary and secondary education across Europe, [19].

Some address a wide range of policy issues from Employment to Health and include Education as part of their brief. Education is considered as one element of many. These wide ranging networks include the Academic Network of European Disability experts (ANED), [20]. The aim of ANED is to establish and maintain a panEuropean academic network in the disability field that will support policy development in collaboration with the Commission's Disability Unit.

Others concentrate on participation in education but consider primary and secondary school and not higher education. The focus of the Network of Experts working on the Social dimension of Education and Training (NESET), [21] is on the social dimension of education which refers to the potential of education and training systems to reduce poverty and enhance equity and social inclusion, laying foundations for the development of more prosperous and more cohesive European societies.

None addresses the specific context of Accessible Digital Transformation in Higher Education. Some aspects of this are considered but not all. The DLEARN network considers Digital Learning and not necessarily how this impacts people with disability, [22]. The European Network for Technology Enhanced Learning in an Inclusive Society (ENTELIS) is a network of organisations with different backgrounds (education, social care, technology, research, advocacy, etc.) committed to full digital inclusion of persons with disabilities and older adults, [23].

There are some projects that consider inclusion in higher education in a wider sense than just people with disability, for example the ACCESS4ALL project, whose aim is to promote the educational and social inclusion of under-represented groups as well as of non-traditional learners, [24]. This reflects the approach of the European University Association who consider people with disability under the wider diversity and inclusion umbrella, [25].

The 2011 report of the Organisation for Economic Co-operation and Development (OECD) points out that tertiary education institutions have been increasingly designing a diverse array of admissions and support strategies for students with disabilities, [26]. However, countries differ in measures to provide pathways to higher education for specified groups including students with disabilities and the way they monitor these pathways, [27]. According to the ENTELIS White paper in line with the social model of disability, inclusive education perceives diversity as part of human nature, and as such the school (and not the student) has to change dramatically in order to provide quality education for all. Typical supports include but are not limited to assistive technology, examination \& assessment accommodations, library supports, respite rooms, and supports such as the provision of scribes and signers, [6]. In the next section the nature of these supports and accommodations is explored further. 


\section{Responding to the Challenge}

\subsection{An Approach to Inclusive Education}

The 2018 Digital Education Action plan which sets out how education and training systems can make "better use of innovation and digital technology and support the development of relevant digital competences needed for life and work in an age of rapid digital change", [5]. It further states that "Digital technology enriches learning in a variety of ways and offers learning opportunities, which must be accessible to all", [5]. The accessibility of learning programs which use digital content and technology is the central concern here. This paper considers the challenges of participation of people with disability in University Education as the use of digital technology grows.

Outside of the legal mandate of providing reasonable accommodation recent initiatives focus on embedding an inclusive education approach into the business practices of higher education. Accessibility is duly considered it in cornerstone activities such as curriculum design, learning processes and content provision. Guidelines such as the Web Content Accessibility Guidelines (WCAG) 2.1 are promoted as best practice, [28]. These Guidelines show how web content can avoid potential accessibility barriers. They specify the requirements of providing alternatives for potentially inaccessible content such as images and audio, the need for properly formed code and the requirement to work with assistive technologies among other recommendations. The guidelines are organised across the four principles of Perceivable, Operable, Understanding and Robust (POUR).

For inclusive course design and delivery approaches such as universal design for learning (UDL) are considered, [29, 30]. UDL provides a blueprint around three principles of Engagement, Representation and Expression for designing strategies, materials, assessments, and tools to reach and teach students with diverse needs.

Engagement is about providing multiple means of engagement to reach high academic goals. This means producing innovative and interesting courses that are flexible enough to engage users in ways that suit the full spectrum of learners to keep them interested and motivated in their chosen studies. Examples of Engagement: Flexible Learning Programs, Negotiated Learning, Multi Pathway Programs, Differentiated Learning.

Expression is about providing alternative ways of demonstrating acquired learning in ways that allow students to showcase their talents in the best ways possible. Examples of Expression: Practical Assessments, Recognition of Prior Learning (RPL), Multiple Forms of Assessment, Group Work, Off-Campus Initiatives (e.g. Students Learning with Communities), Problem Based Learning, Professional Practice.

Representation is about producing inclusive learning materials that typically adhere to Accessibility guidelines and standards such as WCAG 2.1, [28] and provide learners multiple ways of accessing these materials. Examples of Representation: Captioned Videos for Blended Learning, Accessible Websites, Alternative Text across all images.

Universal Design for Learning (UDL) can help educators customise curriculum to serve all learners, regardless of ability, disability, age, gender, or cultural and linguistic background. UDL has been referenced and endorsed by US educational policy and legislation such as the National Educational Technology Plan 2010, [31] and especially the "Every Student Succeeds" Act (ESSA) of 2015 which specifically endorses UDL, [32]. 
UDL has created a framework based on research in the learning sciences, including cognitive neuroscience, that guides the development of flexible learning environments that can accommodate individual learning differences, [29, 30]. However, UDL has not directly addressed the extensive use of digital technologies in education, particularly university education.

\subsection{The Need for a Digital Accessibility Competency Framework in Higher Education}

However, these resources are usually aimed at those with considerable technical knowledge and are often not useful to teachers and other staff in universities who lack the technical background and need resources tailored to their particular contexts of use.

While the introduction of digital technologies in university education has created barriers for students with disabilities, digital technologies can also create new opportunities for these students to improve their access to university education. In terms of teaching, for example, there are now ways to take output from a digital whiteboard and make it available to a screen-reader for blind students, overcoming the problem of not being able to read what a teacher is writing on a blackboard.

There have also been many developments, especially in relation to mobile technology which have increased access to assistive technology in a robust affordable way. Examples of such technology include voice recognition and text to speech available as standard on smart phones. Unfortunately, teachers in university education are often not aware of the possibilities which could improve the learning and assessment experiences of their students with disabilities.

Indeed, a general lack of awareness of the requirements of students with disabilities among faculty staff has been highlighted as a barrier to participation. Van Jaarsveldt and Ndeya-Ndereya have stated, "beyond legislation and institutional policies relating to students with disabilities, academics should accept responsibility for and have an understanding of accessibility and the establishment of inclusive learning", [33].

This begs the question what competences should educators have to effect accessibility in higher education as Digital Transformation takes hold. As a starting point in order to address this question this paper proposes to look at how accessibility may be considered across the competences of the DigCompEdu competency framework.

\section{DigCompEdu as the Basis for a Digital Accessibility Competence Framework for Educators}

Both digital competency frameworks have a strong commitment to accessibility as a crosscutting requirement of all competence areas. The UNESCO ICT CFT Version 3 framework insists on inclusive learning in its mission statement but does not have an specific accessibility competence defined. In contrast, the DigCompEdu framework has an accessibility competence in its Empowering Learners area. Table 1 provides a comparison of the different approaches to Accessibility. 
Table 1. Comparison of framework approaches to accessibility

\begin{tabular}{l|l|l}
\hline $\begin{array}{l}\text { Accessibility } \\
\text { consideration }\end{array}$ & $\begin{array}{l}\text { UNESCO ICT Competency } \\
\text { framework for teachers competence } \\
\text { areas }\end{array}$ & DigCompEdu \\
\hline $\begin{array}{l}\text { Commitment to } \\
\text { accessibility }\end{array}$ & $\begin{array}{l}\text { Recognised in mission statement } \\
\text { Promotes universal design for } \\
\text { learning } \\
\text { Commits to relevant UN sustainability } \\
\text { goals } \\
\text { Insists on inclusive learning } \\
\text { No child left behind }\end{array}$ & $\begin{array}{l}\text { Recognises its significance by } \\
\text { making it a key strand of its } \\
\text { empowering learners } \\
\text { competence area }\end{array}$ \\
\hline $\begin{array}{l}\text { Scope of } \\
\text { accessibility } \\
\text { competencies }\end{array}$ & $\begin{array}{l}\text { Recognised as a traversal cross- } \\
\text { cutting requirement of all areas }\end{array}$ & $\begin{array}{l}\text { Recognised as a traversal cross- } \\
\text { cutting requirement of all areas }\end{array}$ \\
\hline $\begin{array}{l}\text { Specific } \\
\text { accessibility } \\
\text { competencies } \\
\text { defined }\end{array}$ & $\begin{array}{l}\text { A number of accessibility related } \\
\text { objectives and examples are } \\
\text { described for specified competencies } \\
\text { e.g. for the Infusion Competency } \\
\text { which is in the application of digital } \\
\text { skills area }\end{array}$ & $\begin{array}{l}\text { Specific accessibility } \\
\text { competencies defined for all six } \\
\text { levels in the empowering } \\
\text { learners accessibility area }\end{array}$ \\
\hline
\end{tabular}

\subsection{Extending the DigCompEdu Framework}

As stated previously the DigCompEdu framework has an accessibility competence in its Empowering Learners area However while identifying this competence as a requirement across all other competences it needs to show how this may be done. The approach here is to augment existing competences with consideration of accessibility.

In some competences it is simply a matter of extending their reach to include accessibility. For example in the Professional Engagement competence area it is sufficient to extend say Reflective Practice competences to consider how accessible digital technology is or when pursuing Continuous Professional Development in digital skills that Certification in Digital Accessibility is also pursued.

In other competence areas different aspects of UDL need to be embedded into competences. There is strong alignment for example between the UDL Engagement principle Guidelines and the Teaching and Learning Competencies. Assessment Competences are the concern across all three UDL principles, [29, 30]. And there are direct correlations between the objectives of both the Differentiation and Personalization and the Actively Engaging Learners Competences and the UDL Principles of Representation and Engagement respectively, [29, 30].

For other competence areas the WCAG principles, [28] could form the basis of extending the competences to embrace Digital Accessibility. For example the Content Creation competence of the Facilitating Learners Digital Competence Area. The following table summarises possible extensions to the DigCompEdu framework to include Digital Accessibility. 
Table 2. European framework for the digital competence of educators.

\begin{tabular}{|c|c|c|c|}
\hline \multicolumn{2}{|l|}{ Areas } & \multicolumn{2}{|l|}{ Competencies } \\
\hline $\begin{array}{l}\text { Professional } \\
\text { engagement }\end{array}$ & $\begin{array}{l}\text { Organisational } \\
\text { communication (W) } \\
\text { Digital CPD (X) }\end{array}$ & $\begin{array}{l}\text { Professional collaboration } \\
\text { (X) }\end{array}$ & Reflective practice $(\mathrm{X})$ \\
\hline $\begin{array}{l}\text { Digital } \\
\text { resources }\end{array}$ & Selecting $(\mathrm{X})$ & $\begin{array}{l}\text { Creating and modifying } \\
\text { (U) }\end{array}$ & $\begin{array}{l}\text { Managing protecting } \\
\text { and sharing }(\mathrm{X})\end{array}$ \\
\hline $\begin{array}{l}\text { Teaching and } \\
\text { learning }\end{array}$ & $\begin{array}{l}\text { Teaching (U1) } \\
\text { Self-regulated learning } \\
\text { (U1) }\end{array}$ & Guidance (U1) & $\begin{array}{l}\text { Collaborative learning } \\
\text { (U1) }\end{array}$ \\
\hline Assessment & $\begin{array}{l}\text { Assessment strategies } \\
\text { (U) }\end{array}$ & Analysing evidence (X) & $\begin{array}{l}\text { Feedback and planning } \\
\text { (U) }\end{array}$ \\
\hline $\begin{array}{l}\text { Empowering } \\
\text { learners }\end{array}$ & $\begin{array}{l}\text { Accessibility \& } \\
\text { inclusion }\end{array}$ & $\begin{array}{l}\text { Differentiation and } \\
\text { personalization (U2) }\end{array}$ & $\begin{array}{l}\text { Actively engaging } \\
\text { learners (U1) }\end{array}$ \\
\hline $\begin{array}{l}\text { Facilitating } \\
\text { learners } \\
\text { Digital } \\
\text { competence }\end{array}$ & $\begin{array}{l}\text { Information and media } \\
\text { literacy }(\mathrm{W}) \\
\text { Responsible use (X) }\end{array}$ & $\begin{array}{l}\text { Communication (DX) } \\
\text { Problem solving (DX) }\end{array}$ & Content creation (W) \\
\hline Codes & $\begin{array}{l}\text { W - WCAG } \\
\text { compliance } \\
\text { U2 - UDL } \\
\text { representation } \\
\text { DX - Device } \\
\text { knowledge }\end{array}$ & $\begin{array}{l}\text { U - UDL } \\
\text { U3 - UDL action \& } \\
\text { expression }\end{array}$ & $\begin{array}{l}\text { U1 - UDL engagement } \\
\mathbf{X} \text { - Extend to include } \\
\text { accessibility }\end{array}$ \\
\hline
\end{tabular}

In summary, Table 2 shows at a high level the general augmentations that would be necessary to extend this out to include accessibility across all dimensions. However it is not meant to be definitive. Much more work is required to identify at a detailed level the competencies required for true digital accessibility. It is not a trivial challenge. In the next section two case studies are presented that show the scope of this task.

\subsection{The Use of Colour Backgrounds in Digital Content}

Meares-Irlen Syndrome is a perceptual processing disorder characterized by symptoms of visual stress and visual perceptual distortions that are alleviated by using individually prescribed coloured filters, [34]. Unlike dyslexia, it is not a language-based disorder but it is comorbid with dyslexia. Patients susceptible to pattern glare, perceptual distortions and discomfort from patterns, may have Meares-Irlen syndrome and are likely to find coloured filters useful [35].

Using a cream coloured background can enhance reading performance of those with dyslexia and has been recommended by institutions such as the British Dyslexia Association [36]. Given that the colour of the background may impact students, should all teachers be made aware of issues such as this and should the institute make recommendations on the design of content for learning. This knowledge should be the basis of the Content Creation Competency in Facilitating Learners Digital Competence. The question of which competence level it should be pitched at now arises. 


\subsection{Accessible Learning Programs}

Mathematics is traditionally presented as a highly visual subject which is reliant on symbols and spatial arrangements to convey meaning. Many mathematicians still use chalk and blackboards to teach mathematics [37]. Say a blind student is enrolled in the classroom of one of these teachers. The challenges facing both are very significant.

How does an accommodation take place. Is it the responsibility of the teacher or a disability office in the school? Clearly the class notes need to be transformed. Who is responsible for this? What is an appropriate format? The student may have used Nemeth Braille Code previously for studying mathematics, [38].

Does the school have to acquire a Braille device for the student? They may use a screenreader in which case converting to the Mathematical Markup Language MathML, [39] is appropriate.

However in this example it goes way beyond the scope of the content creation competence. It involves policy. Who will undertake the conversion? It involves Teaching. Does the pedagogy change? It involves Assessment. How should the student be assessed?. If an alternative but equivalent accessible assessment process is determined, how is equivalence determined?

Again the question arises as to which competence level these issues need to be included in the framework. These are advanced skills. MathML, for example is considered to be an advanced Web Accessibility skill by the Web Accessibility Initiative, [40].

\subsection{Multi-level Frameworks}

The next stage in the development of a Competency Framework must consider different levels across the competency areas. Both frameworks under consideration specify levels of competency. The UNESCO ICT framework has three and the DigCompEdu has six. Again the question arises as to which competence level these issues need to be included. Proficiency levels of competency is a common feature of frameworks. The EU eCompetence Framework has five levels, [41].

The Web Accessibility Initiative, which is central to this work has recently specified three, basic, Intermediate and advanced [40]. Developing a detailed Digital Accessibility competency framework across all levels will be a complex task. There are 22 competences in the DigCompEdu Framework across six levels of proficiency, that is 132 skills and competences across all levels. Even to specify examples across the three levels of the UNESCO ICT framework for some of the aspects as shown in Table 3 is time consuming and is not definitive.

It is beyond the scope of this work to define these fully and these examples are only included to indicate the detailed future work that is involved here. 
Table 3. Examples at different proficiency levels.

\begin{tabular}{|c|c|c|c|}
\hline $\begin{array}{l}\text { UNESCO ICT } \\
\text { Competency } \\
\text { framework for } \\
\text { teachers } \\
\text { competence areas }\end{array}$ & $\begin{array}{l}\text { Knowledge } \\
\text { Acquisition }\end{array}$ & Knowledge Deepening & Knowledge Creation \\
\hline $\begin{array}{l}\text { Understanding ICT } \\
\text { in education }\end{array}$ & $\begin{array}{l}\text { Policy } \\
\text { understanding } \\
\text { Knowing } \\
\text { accessibility and } \\
\text { equality legislation } \\
\text { relevant to } \\
\text { education }\end{array}$ & $\begin{array}{l}\text { Policy application } \\
\text { Creating digital } \\
\text { accessibility strategies, } \\
\text { conducing compliance } \\
\text { audits and implementing } \\
\text { best practise }\end{array}$ & $\begin{array}{l}\text { Policy innovation } \\
\text { Building a framework } \\
\text { for digital accessibility } \\
\text { in education }\end{array}$ \\
\hline $\begin{array}{l}\text { Application of } \\
\text { digital skills }\end{array}$ & $\begin{array}{l}\text { Application } \\
\text { Audit accessible } \\
\text { digital resources }\end{array}$ & $\begin{array}{l}\text { Infusion } \\
\text { Create and develop } \\
\text { accessible learning objects }\end{array}$ & $\begin{array}{l}\text { Transformation } \\
\text { Design and implement } \\
\text { a digital mathematics } \\
\text { strategy for a screen } \\
\text { reader user }\end{array}$ \\
\hline
\end{tabular}

\section{Accessible Learning Programs}

\subsection{The Experiences of Two Digital Accessibility Courses}

While efforts to establish competency frameworks with respect to digital transformation in education are to be lauded and their commitment to digital accessibility is noteworthy, the challenge ahead should not be underestimated. It is one thing identifying Digital Accessibility competencies, it is another to impart that knowledge to educators.

The author has many years experience of teaching topics in Universal Design and assistive ICT to computer science students and has also participated in the recently completed Massive Open Online Course for Accessibility Partnership project (MOOCAP), funded by the ERASMUS+ Key Action 2 (KA2) grant program of the European Union, [42]. This had the twin aims of establishing a strategic partnership around the promotion of Universal Design and Accessibility for ICT professionals and of developing a suite of Open Educational Resources (OERS) in this domain. Both of these initiatives have digital accessibility as a common learning goal, reflecting the reported need to promote accessibility considerations amongst ICT professionals. There have been some interesting experiences on both of these initiatives which have relevance for this discussion.

\subsection{The Universal Design and Assistive ICT Courses and on the MOOCAP Digital Accessibility Course}

When computer science students were surveyed prior to the Universal Design and Assistive ICT courses they mostly responded that they had little knowledge of digital accessibility. The fact that these are computer science students where accessibility should be part of their core knowledge since it is mandated by law and EU directives, 
probably points to a wider awareness issue. The implication for Digital Accessibility competency frameworks is that there is likely to be low awareness of these topics. It is also important to pitch Digital Accessibility competences in an appropriate manner for educators.

This was an interesting feature of the MOOCAP project. This was originally targeted at ICT professionals as envisaged by the CEN Community Workshop Agreement (CWA) Curriculum for training ICT Professionals in Universal Design, CWA 16266 [43]. These were software developers, ICT managers and others working in the ICT professions. However of those who completed the pre-course survey only $19 \%$ were from IT backgrounds. Anecdotal evidence provided in the discussion fora indicated that many from ICT were content providers rather than programmers or developers. The largest group (25\%) were from Teaching and Education backgrounds. This had a significant impact on the delivery of the course.

If the topic involved computer science subject matter such as where the Web Content Accessibility Guidelines, [28] were presented in technical HTML terms, students responded through online fora that this was difficult subject matter for them. The consequence of this for a competence framework is that if the content is very technical then the intended audience may be lost.

Based on both of these experiences it is essential to deliver competency education in Digital Accessibility in clear terms pitched at the right level. Do not assume prior knowledge on behalf of participants. Based on personal teaching experience it is important to root Digital Accessibility knowledge in personal experiences. For example not being able to see a poorly contrasted app on a phone when the sun is shining is an experience that many have had. By highlighting this digital accessibility is framed in terms of barriers they have personally encountered and leads to a greater engagement with the topic. This would have been borne out by animated discussions around certain topics such as online banking in the MOOCAP Digital Accessibility course, [44].

\subsection{Conclusions}

It is essential to promote digital accessibility knowledge amongst the educators at the front line of the Digital Transformation. While competency frameworks consider accessibility it is necessary to elaborate on this dimension. This is a considerable challenge in its own right. There are many competences already defined for Digital Technology in education. These need to be augmented with the broad knowledge of competences ranging from Content Accessibility knowledge such as WCAG, [28] to the many dimensions of UDL, [29, 30]. Many other topics including the accessibility of devices need also be considered.

The development of a Digital Accessibility Competence Framework must be met with urgency. It must be acknowledged that this will not be a trivial task. It will involve a detailed analysis of the competences required across many levels of proficiency. However this challenge must be met.

If the full opportunity of Digital Technology is to be taken, then this must be backed up by the knowledge and skills of the educators. Without the necessary competences the Digital Divide as envisaged by ENTELIS will grow as the Digital Transformation in education grows, [6]. 


\section{References}

1. Higher Education Authority (HEA): Digital Transformation and Empowering Technologies in Higher Discussion Paper (2019). http://hea.ie/assets/uploads/2017/04/190212_ FutureFocus_Digital-Transformation_Discussion-Paper.pdf. Accessed 22 Feb 2020

2. European Digital Strategy. https://ec.europa.eu/digital-single-market/. Accessed 22 Feb 2020

3. European Commission/EACEA/Eurydice. The European Higher Education Area in 2018: Bologna Process Implementation Report. Publications Office of the European Union, Luxembourg (2018)

4. European Commission Communication 'Strengthening European Identity through Education and Culture', Gothenberg (2017): https://ec.europa.eu/commission/sites/beta-political/files/ communication-strengthening-european-identity-education-culture_en.pdf. Accessed 22 Feb 2020

5. European Commission, Digital Education Plan (2018). https://ec.europa.eu/education/sites/ education/files/digital-education-action-plan.pdf. Accessed 22 Feb 2020

6. Hoogerwerf, E.-J., et al.: Digital inclusion. a white paper (2016). https://www.entelis.net/en/ node/349. Accessed 22 Feb 2020

7. European Parliament, Recommendation of the European Parliament and of the Council of 18 December 2006 on key competences for lifelong learning (2006). https://eur-lex.europa.eu/ legal-content/EN/TXT/?uri=CELEX\%3A32006H0962. Accessed 22 Feb 2020

8. European Commission, Council Recommendation on Key Competences for Lifelong Learning (2018). https://ec.europa.eu/education/sites/education/files/recommendation-keycompetences-lifelong-learning.pdf. Accessed 22 Feb 2020

9. Carretero Gomez, S., Vuorkari, R., Punie, Y.: DigComp 2.1: The Digital Competence Framework for Citizens with eight proficiency levels and examples of use (2017). https://ec. europa.eu/jrc/en/publication/eur-scientific-and-technical-research-reports/digcomp-21digital-competence-framework-citizens-eight-proficiency-levels-and-examples-use. Accessed 22 Feb 2020

10. Redecker, R., Punie, Y.: European Framework for the Digital Competence of Educators: DigCompEdu (2017). https://ec.europa.eu/jrc/en/digcompedu. Accessed 22 Feb 2020

11. Kampylis, P., Punie, Y., Devine, J.: Promoting Effective Digital-Age Learning: A European Framework for Digitally-Competent Educational Organisations (2015). https://ec.europa.eu/ jrc/en/digcomporg/framework. Accessed 22 Feb 2020

12. UNESCO ICT Competency Framework for Teachers, version 3 (2018). https://unesdoc. unesco.org/ark:/48223/pf0000213475. Accessed 22 Feb 2020

13. United nations (UN) resolution, Transforming our world: the 2030 Agenda for Sustainable Development (2015). http://www.un.org/ga/search/view_doc.asp?symbol=A/RES/70/ $1 \&$ Lang=E. Accessed 22 Feb 2020

14. Ridell, S.: The inclusion of disabled students in higher education in Europe: Progress and challenges. In: UNIversal Inclusion Rights and Opportunities for Persons with Disabilities in the Academic Context Conference, Italian University Conference of Delegates for Disabilities in collaboration with the Università degli Studi di Torino, the Politecnico di Torino, and the Università degli Studi del Piemonte Orientale, Turin (2016)

15. UNESCO: The Salamanca Declaration and Framework for Action on Special Needs Education (1994). https://unesdoc.unesco.org/ark:/48223/pf0000098427. Accessed 22 Feb 2020

16. UN-CRPD: Convention on the rights of persons with disabilities. United Nations, New York (2006) 
17. UN Sustainable Development Goal 4. https://sustainabledevelopment.un.org/sdg4. Accessed 22 Feb 2020

18. Ebersold, S., Schmitt, M.J., Priestley, M.: Inclusive Education for Young Disabled People in Europe: Trends, Issues and Challenges: A Synthesis of Evidence from ANED Country Reports and Additional Sources (2011). http://www.disability-europe.net/. Accessed 07 July 2019

19. UDLnet-Universal Design for Learning. http://www.udlnet-project.eu/. Accessed 22 Feb 2020

20. Academic Network of European Disability Experts (ANED). https://www.disability-europe. net/. Accessed 22 Feb 2020

21. Network of Experts working on the Social dimension of Education and Training (NESET). https://nesetweb.eu/en/about-us/. Accessed 22 Feb 2020

22. European Digital Learning Network (DLEARN). http://dlearn.eu/. Accessed 22 Feb 2020

23. European Network for Technology Enhanced Learning in an Inclusive Society (ENTELIS) https://www.entelis.net/en. Accessed 22 Feb 2020

24. ACCESS4ALL project. https://access4allproject.eu. Accessed 22 Feb 2020

25. European University Association. https://eua.eu/. Accessed 22 Feb 2020

26. The Organisation for Economic Co-operation and Development (OECD), Inclusion of Students with Disabilities in Tertiary Education and Employment, Education and Training Policy. OECD, Paris (2011)

27. Commission/EACEA/Eurydice, European Commission, Modernisation of Higher Education in Europe: Access, Retention and Employability, Eurydice report (2014). http://eacea.ec. europa.eu/education/eurydice/documents/thematic_reports/165EN.pdf. Accessed 22 Feb 2020

28. Web Content Accessibility Guidelines (WCAG) 2.1. https://www.w3.org/TR/WCAG21/. Accessed 22 Feb 2020

29. Universal Design for Learning (UDL) guidelines. http://udlguidelines.cast.org/. Accessed 22 Feb 2020

30. Universal Design for Learning (UDL). https://www.ahead.ie/udl. Accessed 22 Feb 2020

31. U.S. Department of Education, Office of Educational Technology, Transforming American Education: Learning Powered by Technology, Washington, D.C. (2010). https://www.ed. gov/sites/default/files/netp2010.pdf, http://udlguidelines.cast.org/. Accessed 22 Feb 2020

32. Every Student Succeeds: Act (ESSA) (2015). http://www.everystudentsucceedsact.org/. Accessed 22 Feb 2020

33. Jaarsveldt, D., Ndeya-Ndereya, C.: 'It's not my problem': exploring lecturers' distancing behaviour towards students with disabilities. Disabil. Soc. 30, 1-14 (2015). https://doi.org/ 10.1080/09687599.2014.994701

34. Rello, L., Bigham, J.: Good background colors for readers: a study of people with and without Dyslexia. In: ASSETS 2017: Proceedings of the 19th International ACM SIGACCESS Conference on Computers and Accessibility, October 2017, pp. 72-80 (2017). https://doi.org/10.1145/3132525

35. Evans, B.J., Cook, A., Richards, I.L., Drasdo, N.: Effect of pattern glare and colored overlays on a simulated-reading task in dyslexics and normal readers. Optom. Vis. Sci. 71 (10), 619-628 (1994)

36. British Dyslexia Association: Dyslexia style guide (2012). http://www.bdadyslexia.org.uk/

37. Billman, A., Harding, A., Engelbrecht, J.: Does the chalkboard still hold its own against modern technology in teaching mathematics? A case study. Int. J. Math. Educ. Sci. Technol. 49(6), 809-823 (2018). https://doi.org/10.1080/0020739X.2018.1431852 
38. American Association of Workers for the Blind, Association for Education of the Visually Handicapped, and the National Braille Association, The Nemeth Braille Code for Mathematics and Science Notation 1972 Revision. http://www.brailleauthority.org/ mathscience/nemeth1972.pdf. Accessed 22 Feb 2020

39. MathML. https://www.w3.org/Math/. Accessed 22 Feb 2020

40. Web Accessibility Initiative (WAI) curricula. https://www.w3.org/WAI/curricula/. Accessed 22 Feb 2020

41. European eCompetence Framework. https://www.ecompetences.eu/. Accessed 22 Feb 2020

42. MOOCs for Accessibility Partnership (MOOCAP). https://moocap.gpii.eu/. Accessed 22 Feb 2020

43. Comite Europeen de Normailisation (CEN) Community Workshop Agreement (CWA) Curriculum for training ICT Professionals in Universal Design, CWA 16266 (2011)

44. Gilligan, J., Chen, W., Darzentas, J.: Using MOOCs to promote digital accessibility and universal design, the MOOCAP experience. Stud. Health Technol. Inform. 256, 78-86 (2018) 